\title{
モータ積層鉄心の性能に及ぼす層間短絡の影響
}

\author{
正員開道 力* 正員茂木 尚* \\ 非会員 半澤 和文**
}

\section{The Effect of Short Circuit between Laminated Steel Sheets on the Performance of Lamination Core of Motor}

Chikara Kaido*, Member, Hisashi Mogi*, Member, Kazufumi Hanzawa**, Non-member

The effects of short circuits between laminated steels in lamination cores, caused by clinching or welding, are discussed in this paper. A short circuit between laminated steels increase a core loss. A short-circuit resistance $r_{1}$ due to clinching is more affected by contact resistance than by the electrical resistivity of core material and it is inversely as the third order of the thickness of core material. In the case of welding, $r_{1}$ is influenced by the resistivity of core material and it is inversely as the second order of core material thickness, if the width and depth of welding, such as laser welding, are proportional to the thickness. The short-circuit resistance of welding is generally smaller than that of clinching, and then the short-circuit loss caused by welded core will be larger than that by clinching. According to theoretical calculation, the short-circuit losses are possibly larger than iron losses due to core materials in actual cores and more than two times in the case of segment motor cores, because the number of clinch-ing or welding is large. As the method to reduce the short-circuit losses or to avoid the short circuits, it is necessary to use thin electrical steel sheets with high electrical resistivity as core materials, or to fix laminated steels by means of adhesion or molding.

キーワード : 積層鉄心, 短絡, かしめ, 溶接, 電磁鋼板

Keywords : lamination core, short circuit, clinching, welding, electrical steel sheet

\section{1. 緒言}

モータは，エネルギー環境問題に伴い，高効率低損失化 が要求され(1), モ一夕損失の低減には低鉄損鉄心材料を使 用する必要がある。しかし，モータ鉄損は鉄心の使用条件 にも影響される。実際のモータにおける鉄心材料の使用状 態は, 図 1 のように, 鉄心素材が通常の評価条件(均一, 交番磁界, 正弦波, 無応力, 室温) とは大きく異なり ${ }^{(2)}$, 次 の点がモータの鉄損に影響している。

（1）多次元磁気挙動 [例えば，磁束分布，回転磁束な ど]

（2）非正弦波励磁[例えば，時間高調波，空間高調波 など]や偏磁 [例えば，磁束重畳など $]$

（3）鉄心材料加工やモータ組立工程で生じる歪や応力

* 新日本製鐵侏技術開発本部鉄鋼研究所鋼材第一研究部 干293-8511 富津市新富 20-1

Steel Products Lab.- I, Steel Research Laboratories, Technical Development Bureau, Nippon Steel Corporation

20-1 Shintomi, Futtsu 293-8511

** 新日本製鐵(㑣)八幡製鐵所電磁鋼板工場

厂 804-8501 北九州市戸畑区飛幡 1-1

Electrical Sheet Mill, Yawata Works, Nippon Steel Corporation

1-1 Tobihata, Tobata, Kitakyushu 804-8501
（4）鉄心の積層結束と固定で生じる積層間短絡電流の 発生

(5) 鉄心温度

これら鉄心素材の使用条件が実機のモータ鉄損に影響し ている。（1）や（2）については数值解析などで検討は既に

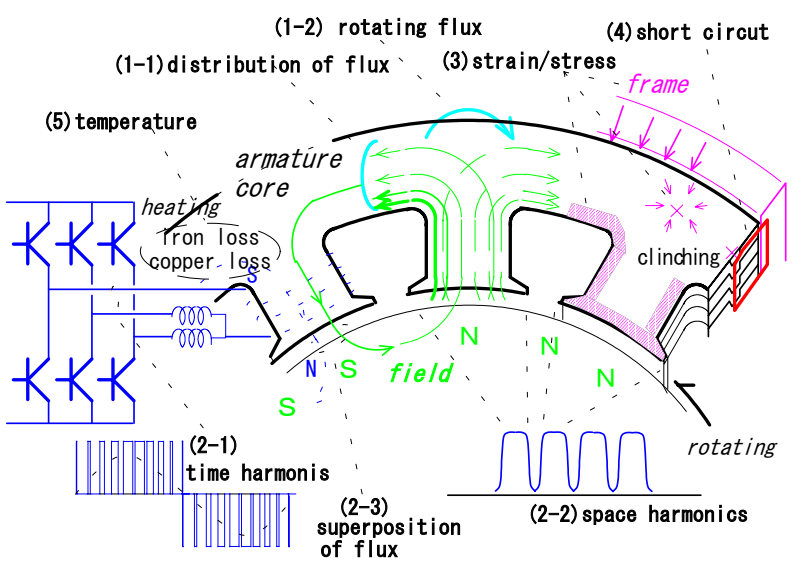

図 1 モータにおける鉄心，鉄心素材の使用条件

Fig. 1. The exciting conditions of motor cores and the materials. 
進んでいる。しかし，（３），（4）は殆ど考慮されていな い。歪, 応力は実際の歪応力を評価, 管理することが難し く, 実モータでの検討はあまり進んでいなかったが, 最 近，解析などで考慮されはじめた。モータ鉄心の電磁鋼板 積層の結束や固定による層間短絡もモー夕鉄損への影響も 大きい。電磁鋼板積層の結束のためにかしめ, 溶接などが 使用され，モータケースへの鉄心固定には圧入，焼き嵌 め, ボルト締めが使用される。この場合, 積層された電磁 鋼板は積層間で電気的に短絡されることが多い。短絡が二 箇所以上ある場合には，短絡端と電磁鋼板で電気的に閉回 路を構成することになり，この閉回路と鎖交する磁束があ れば短絡電流が流れ, 損失が生じる。しかし, これらの要 因はモータ製造上，コストや生産性のために避けられない 要因でもある。

本報告では，モータの積層鉄心における結束や鉄心固定 による積層鉄心の層閒短絡について検討してみる。

\section{2. 積層鉄心における短絡損失の理論式}

モータ積層鉄心の短絡電流による損失を検討する。例え ば，図1(4)のように，かしめとケースの 2 短絡部の短絡 を考えて，この短絡回路を含む断面(図 1 表示の短絡断面) を図 2 で表し解析モデルとした。鉄心の積層厚を $H$ とし， 積層方向で中心に対して対称と考えられるので, 中心から の積層方向位置を $x$ とした。両短絡部間の距離を $w$ とし, 両短絡部間の断面積 $H w$ を通り, 短絡回路と鎖交する平均 磁束密度を $B$ とする。両短絡部の各単位長あたりの短絡抵 抗 $r_{1}, r_{2}$ の和を $r_{\mathrm{S}}[\Omega / \mathrm{m}]$, 短絡部間の単位積層厚あたりの積 層鋼板の抵抗を $r_{\mathrm{C}}[\Omega \mathrm{m}]$ とすると, 励磁角周波数 $\omega$, 短絡部 の電流 $I(x)$, 両短絡部の逆起電力の和 $V(x)$ に対して,

$$
\begin{aligned}
& I(x)=\frac{1}{r_{\mathrm{S}}} \frac{\partial V(x)}{\partial x} \ldots \ldots \ldots \ldots . . . . . . \\
& \omega B w x=V(x)-r_{\mathrm{C}} \frac{\partial I(x)}{\partial x}
\end{aligned}
$$

が成り立つので，下記の微分方程式が得られる。

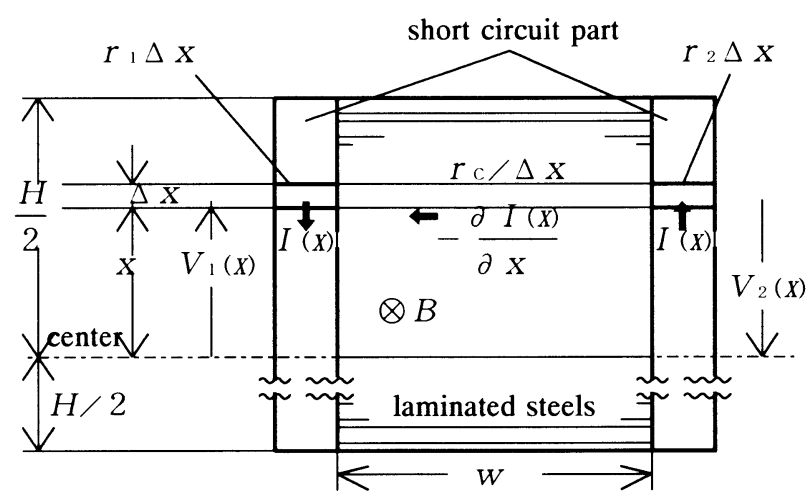

図 2 層間短絡状態の電圧と電流

Fig. 2. Voltage and current in a short circuit between laminations.

$$
\frac{\partial^{2}}{\partial x^{2}} V(x)=\frac{r_{\mathrm{S}}}{r_{\mathrm{C}}}\{V(x)-\omega B w x\}
$$

そこで, $\sqrt{r_{\mathrm{C}} / r_{\mathrm{S}}}$ を基準積層厚 $x_{0}$ として,$x$ と $H$ を $x_{0}$ で 規格化した $u=x / x_{0}, \quad h=H /\left(2 x_{0}\right)$ と基準電圧 $V_{0}=\omega B w x_{0}$, 基準電流 $I_{0}=\omega B \mathrm{w} / r_{\mathrm{S}}$ を用いて解を求めた。初期条件を $x$ $=0$ のとき $V(x)=0, x=H / 2$ のとき, $I(x)=0$ として,$B$ 一定として解を求めると,

$$
\begin{aligned}
& V(x)=V_{0}\{u-\sinh (u) / \cosh (h)\} \\
& I(x)=I_{0}\{1-\cosh (u) / \cosh (h)\}
\end{aligned}
$$

短絡による全短絡損失 $W_{\mathrm{T}}$ は, 短絡端自身での損失 $W_{\mathrm{S}}$ と 短絡間の鋼板での損失 $W_{\mathrm{C}}$ に分けて考えると,

$$
\begin{aligned}
W_{\mathrm{S}} & =\int r_{\mathrm{S}}\{I(x)\}^{2} d x \\
& =\frac{W_{0}}{2}\left(3-3 \frac{\tanh (h)}{h}-\tanh ^{2}(h)\right) \\
W_{\mathrm{C}} & =\int r_{\mathrm{C}}\left(\frac{\partial I(x)}{\partial x}\right)^{2} d x \\
& =\frac{W_{0}}{2}\left(\frac{\tanh (h)}{h}-1+\tanh ^{2}(h)\right) \cdots \\
W_{0} & =\omega^{2} B^{2} w^{2} H / r_{\mathrm{S}}=2 h V_{0} I_{0} \cdots \cdots \cdots \cdots
\end{aligned}
$$

となり, 全短絡損失 $W_{\mathrm{T}}$ は次式となり, 短絡抵抗 $r_{\mathrm{S}}$ が小さ いと基準損失 $W_{0}$ は増大するので，短絡損失は増加する。

$$
W_{\mathrm{T}}=W_{0}\left(1-\frac{\tanh (h)}{h}\right) \text {. }
$$

$h$ が大きい(積層間短絡抵抗が積層鉄心抵抗より大きい) 場合，全短絡損失 $W_{\mathrm{T}}$ は,

$$
W_{\mathrm{T}} \fallingdotseq W_{0}(1-1 / h)
$$

となり，ほぼ $W_{0}$ に等しくなる。短絡電流は(5)式より，

$$
I(x)=I_{0}\{1-\exp (u-h)\}
$$

で示される。従って，積層両端の近傍を除けば，短絡電流 はほぼ一定の $I_{0}$ となり, 積層鋼板の両短絡間に流れる電流 $\partial I(x) / \partial x$ は殆ど 0 になる。従って, 鋼板での損失 $W_{\mathrm{C}}$ は,

$$
W_{\mathrm{C}} \fallingdotseq W_{0} /(2 h)=V_{0} I_{0}=I_{0}{ }^{2} r_{\mathrm{C}} / x_{0}
$$

となり, 積層鋼板の両短絡端のみで発生し, 非常に小さく なり，全短絡損失 $W_{\mathrm{T}}$ において無視できることがわかる。

\section{3. 実際の鉄心における $r_{\mathrm{S}}$ と $r_{\mathrm{C}}$ の概算}

一方の短絡端がかしめや溶接等で，他方の短絡端がケー スなどの面接触短絡で短絡抵抗が極めて低いとして， $r_{\mathrm{S}}$ や $r_{\mathrm{C}}$ を概算してみる。

先ず， $r_{\mathrm{C}}$ を概算する。かしめや溶接などの接触状態が等 価的に円柱状接触(直径 $D$ ) と見なされ, 他方の短絡端が平 面で，短絡間の距離を $w$ とする場合，鉄心と短絡端の間の 接触抵抗を無視すると, $D \ll w$ のとき， $r_{\mathrm{C}}$ は，鉄心素材の 
電気抵抗率を $\rho_{\mathrm{C}}$ として, 次式となり,

$$
r_{\mathrm{C}}=\frac{\rho_{\mathrm{C}}}{2 \pi} \ln (2 w / D)
$$

となり，オーダー的に $\rho_{\mathrm{C}}$ であることがわかる。

次に， $r_{\mathrm{S}}$ を概算する。かしめの場合，積層鋼板間は接触 で短絡し短絡電流は蛇行する。接触部の数は板厚 $t$ に反比 例する。このような場合でも, 溶接の場合と同様に, 短絡 電流路の長さ $\ell_{\mathrm{s}}$ は積層厚 $H$ に比例すると考えられる。短 絡電流路の面積 $S_{\mathrm{S}}$ は，かしめやレーザ溶接の大きさや深さ はおよそ板厚 $t$ に比例するので, $t^{2}$ に比例する。従って, 単位積層厚あたりの短絡抵抗 $r_{\mathrm{S}}$ は次式で表せる。

$$
r_{\mathrm{S}}=\frac{k_{\mathrm{SL}} \rho_{\mathrm{C}}+2 \xi / t}{S_{\mathrm{S}}}=\frac{k_{\mathrm{SL}} \rho_{\mathrm{C}} t+2 \xi}{k_{\mathrm{SC}} t^{3}}
$$

\section{$k_{\mathrm{SL}}$ : 短絡電流路 $\ell_{\mathrm{S}} /$ 積層厚 $H$ の実効的な比率}

$k_{\mathrm{SC}}$ : 短絡路断面積 $S_{\mathrm{S}} / t^{2}$ の実効的な比率

$\xi:$ 接触抵抗 $\left[\Omega \mathrm{m}^{2}\right]$

従って，溶接のように，接触部が無く， $\boldsymbol{\xi}=0$ では $\boldsymbol{r}_{\mathbf{s}}$ は $t^{2}$ に, 逆に, 接触抵抗が大きいとき, $t^{3}$ に反比例する。

実際に，かしめや溶接による短絡端の短絡抵抗 $r_{1}$ を実測 した。表 1 はかしめや溶接を行った結束条件, 表 2 は短絡 抵抗 $r_{1}$ の実測值と予想值, 換算值を示す。短絡抵抗は 4 端 子法を用い, 積層鉄心の積層両端から電流を流し, 電圧は 積層端部で測定した。複数の短絡端がある場合は, 全短絡 端の抵抗が同じとして短絡抵抗を計算した。短絡抵抗を実 際に測定した結束状態あるいは類する状態の写真を図 3 〜 図 5 に示す。表 1 の係数換算值は図 3 〜図 5 で電流路の断 面積, 長さを想定し, 寸法を板厚に対する倍率で求め, $k_{\mathrm{SC}}, k_{\mathrm{SL}}$ を算定した。表 2 の予想值は $\xi=0$ (接触抵抗無視)

表 1 かしめ, 溶接の結束条件

Table 1. The conditions of clinching and welding.

\begin{tabular}{|l|l|l|l|l|l|l|}
\hline \multirow{2}{*}{\multicolumn{1}{c|}{\begin{tabular}{c}
\multicolumn{1}{c|}{ clinching } \\
or welding
\end{tabular}}} & \multicolumn{2}{c|}{ steel sheet } & \multicolumn{2}{c|}{ size $(\mathrm{mm})$} & \multicolumn{2}{c|}{ coefficient } \\
\cline { 2 - 8 } & $t^{* 1}$ & $\rho_{\mathrm{C}}{ }^{* 1}$ & width & depth & $k_{\mathrm{SC}}$ & $k_{\mathrm{S}}$ \\
\hline V-clinching*2 & 0.15 & 0.64 & $0.8 \times 2$ & $3 t / 2$ & 40 & 2 \\
round-clinching & 0.15 & 0.64 & $1 \phi$ & $t / 2$ & 10.5 & 2 \\
\hline laser welding & 0.35 & 0.52 & $2 t$ & $0.7 t$ & 1.4 & 1 \\
TIG-welding & 0.50 & 0.15 & 3 & 1 & 12 & 1 \\
\hline
\end{tabular}

*1: $t$ :thickness $(\mathrm{mm}) \quad \rho_{\mathrm{C}}$ :resistivity $(\mu \Omega \mathrm{m})$

*2 : clinched by Mitsui High-tec Inc.

表 2 かしめ, 溶接の $r_{1}$ 実測例

Table 2. The measured $r_{1}$ of clinching or welding.

\begin{tabular}{|l|cc|c|}
\hline \multirow{2}{*}{$\begin{array}{l}\text { clinching } \\
\text { or welding }\end{array}$} & \multicolumn{3}{|c|}{ short circuit resistance $r_{1}(\Omega / \mathrm{m})$} \\
\cline { 2 - 3 } V-clinching & measured & transformed into same sheet*2 \\
round-clinching & $15)^{* 1}$ & $2.6 \quad(0.15)^{* 1}$ \\
\hline laser welding & $2.5(3.0)$ & $0.32(0.11)$ \\
TIG-welding & $0.05(0.05)$ & $0.046(0.05)$ \\
\hline
\end{tabular}

*1 : estimated by the size at contact resistance $0 \Omega \mathrm{m}^{2}$.

$* 2$ : transformed into $0.5 \mathrm{~mm}$ (thickness), $0.15 \mu \Omega \mathrm{m}$
として, 表 1 の係数推定值と(14)式より求めた值で, 換算 值は更に板厚 $0.5 \mathrm{~mm}$, 電気抵抗率 $15 \mu \Omega \mathrm{cm}$ に換算した予 測值である。

かしめの短絡は, 図 3 , 図 4 のように, 接触によるもの で, かしめ方法で短絡面積が異なる。写真より接触面積を 推定し短絡抵抗を予想すると, かしめの短絡抵抗 $\boldsymbol{r}_{\mathrm{S}}$ の実測 值は推定值より大きいことが表 2 より明らかであり, 接触 抵抗 $\xi$ の影響が大きい。一方, 溶接の場合は, 図 5 のよう に, 溶接部は鋼板が再溶解して柱状に一体になり層間短絡 が生じており, この再溶解部分から $r_{\mathrm{s}}$ を計算した推定值は 実測值と良く一致している。従って, 溶接のように, 接触 抵抗が無視できる場合は(14)式より， $\boldsymbol{r}_{\mathrm{S}}$ は鉄心素材の電気 抵抗率に比例, $t^{2}$ に反比例する。かしめのように, 接触抵 抗の影響が大きく, $r_{\mathrm{S}}$ が大きい場合は鉄心素材の電気抵抗 率の影響が小さくなり，短絡抵抗は $t^{3}$ に反比例する。

このように, 短絡抵抗 $\boldsymbol{r}_{\mathrm{s}}$ は結束方法で異なり, 溶接の方 がかしめより小さく $r_{\mathrm{s}}$ が大きくなる。また， $\boldsymbol{r}_{\mathrm{s}}$ は(14)式よ り板厚が薄くなると大きくなるので, 短絡損失は鉄心素材 薄手化で低減できる。従って, 短絡損失の低減方法として は結束方法の最適化と鉄心素材の薄手化が可能である。

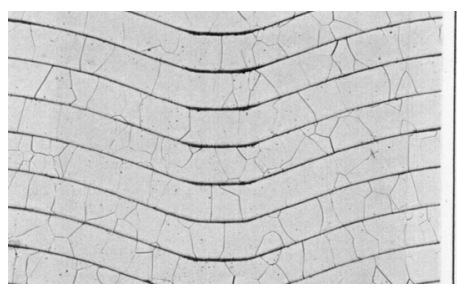

R.D.-crosssection

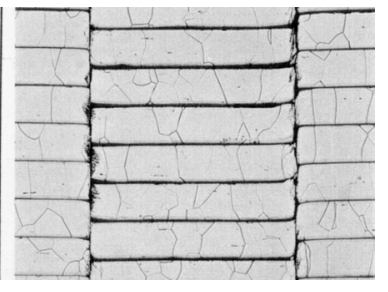

T.D.-crosssection
図 3 Vかしめ

Fig. 3. V-clinching.

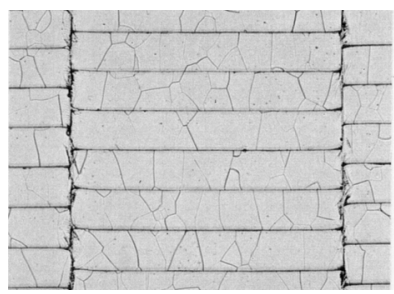

R.D.-crosssection

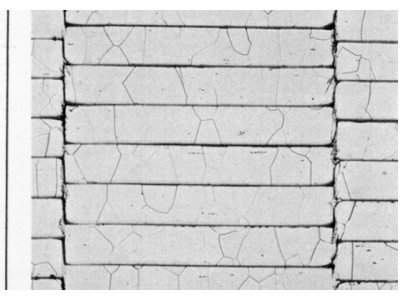

T.D.-crosssection
図 4 丸平かしめ

Fig. 4. Round-clinching.
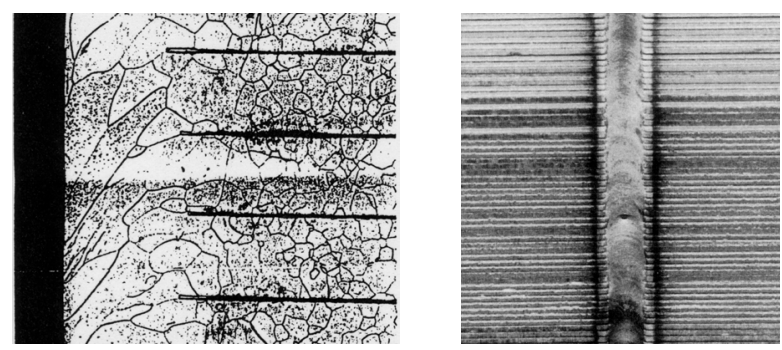

図 5 TIG 溶接

Fig. 5. TIG welding. 
これらの結果を基に，hの大きさを検討してみると，

$$
h=\frac{H}{2 x_{0}^{0.5}}=\left(\frac{\pi\left(k_{\mathrm{SL}} t+\xi / \rho_{\mathrm{C}}\right)}{2 k_{\mathrm{SC}} t \ln (2 w / D)}\right)^{0.5} N_{\mathrm{C}}
$$

となる。ここで， $N_{\mathrm{C}}$ は積層鉄心の積層数である。一般的 に, $k_{\mathrm{SC}} / k_{\mathrm{SL}}<25, \ln (2 w / D)<2 \pi$ であるので, 接触抵抗 $\xi$ が無視できれば,

$$
h>\left(\frac{\pi k_{\mathrm{SL}}}{2 k_{\mathrm{SC}} \ln (2 w / D)}\right)^{0.5} N_{\mathrm{C}}>\frac{N_{\mathrm{C}}}{10} .
$$

となる。積層数 $N_{\mathrm{C}}$ が大きく 30 以上であれば $h>3$ とな り，[2-13]式が成り立つことがわかる。積層厚さが薄く， 積層数が少なくなり, $h<1$ となると, 短絡部の抵抗だけで なく, 鉄心自身の抵抗も影響するようになるが，単位体積 あたりの短絡損失が小さくなり，短絡の影響は小さくなる。

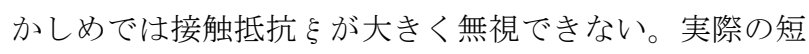
絡抵抗 $\boldsymbol{r}_{\mathrm{s}}$ は表 2 より接触抵抗を無視した值に対し，Vかし めで 17 ，丸平かしめで 2 であり，Vかしめの方が短絡抵抗 が大きくなり，短絡損失の低減のためには適している。

\section{4. 実際の鉄心における短絡損失}

〈4·1〉短絡回路との鎖交磁束に対する短絡損失 実 際に，短絡回路との鎖交磁束で生じる短絡損失を考える。 短絡損失は 鉄心素材の電気抵抗率 $\boldsymbol{\rho}_{\mathrm{C}}$ の影響が強いので, 鉄心の鉄損に対する損失増加を容易に見積もるために， $\rho_{\mathrm{C}}$ と関連が強い素材の渦電流損 $W_{\mathrm{e}}$ との短絡損失比で検討寸 る。図 2 のように, 二箇所の短絡 (一短絡対) による短絡電 気回路と鎖交する磁束量を $\Phi[=B H w]$ として,

$$
\begin{aligned}
& K_{\mathrm{S}}=\omega^{2} \Phi^{2} /\left(r_{\mathrm{S}} H W_{\mathrm{e}}\right)=W_{0} / W_{\mathrm{e}} \\
& K_{\mathrm{C}}=\omega^{2} \Phi^{2} /\left(12 r_{\mathrm{C}} W_{\mathrm{e}}\right)
\end{aligned}
$$

とすると, 一般的に $h$ は大きいので, $W_{\mathrm{S}} \fallingdotseq K_{\mathrm{S}} W_{\mathrm{e}}, W_{\mathrm{C}} \fallingdotseq$ $K_{\mathrm{C}} W_{\mathrm{e}}$ であり，全短絡損失も $W_{\mathrm{T}} \fallingdotseq K_{\mathrm{S}} W_{\mathrm{e}}$ となる。

$W_{\mathrm{e}}$ は, 一短絡対が対応する磁路長を $\ell$ とて,

$$
\begin{aligned}
& W_{\mathrm{e}}=\frac{\omega^{2} \Phi^{2} \ell}{\sigma_{\mathrm{e}} H w} \ldots \ldots . \\
& \sigma_{\mathrm{e}}=12 \rho_{\mathrm{C}} /\left(\eta t^{2}\right)
\end{aligned}
$$

で表せる。ここで， $\sigma_{\mathrm{e}}, \quad \eta$ は 鉄心素材の渦電流損係数, 古 典理論值に対する実際の渦電流損の比率(3)であり, 市販電 磁鋼板の $\eta$ は 1 2 である。従って, 短絡損失比率 $K_{\mathrm{S}}$ は, (17)〜(19)式より，

$$
K_{\mathrm{S}}=\frac{w \sigma_{\mathrm{e}}}{\ell r_{\mathrm{S}}}=\frac{12 w}{\eta \ell} \frac{k_{\mathrm{SC}}}{\xi /\left(\rho_{\mathrm{C}} t\right)+k_{\mathrm{SL}}}
$$

となり， $K_{\mathrm{S}}$ は一定であることがわかる。従って，一般に， $W_{\mathrm{T}} \fallingdotseq K_{\mathrm{S}} W_{\mathrm{e}}$ なので, 全短絡部損失 $W_{\mathrm{T}}$ は鉄心素材の渦電流損 に比例する。従って，低鉄損の高級無方向性電磁鋼板を用 いると, 素材鉄損だけでなく短絡損失も小さくなることが わかる。層間結束が溶接である場合 $\left(\xi=0, k_{\mathrm{SL}}=1\right), k_{\mathrm{SC}}$

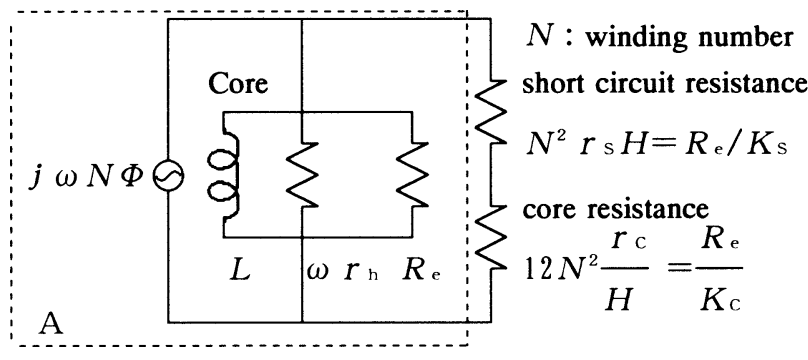

図 6 積層間短絡部の近似等価回路

Fig. 6. An approximate equivalent circuit in the core part of short circuit between laminated steels.

$=1, \eta=1$ とすると, $\ell=12 w$ としても $K_{\mathrm{S}}=1$ となり, 素 材鉄損に対して無視できないことが分かる。

$K_{\mathrm{S}}$ は $r_{\mathrm{S}}$ すなわち短絡状態 $\left(k_{\mathrm{SC}}, k_{\mathrm{SL}}, \xi\right)$ で大きく変化する もので, モータ製造条件で変動する。 $K_{\mathrm{C}}$ は鉄心構造 (短絡 位置と積層鉄心)で決まる定数で短絡状態に殆ど影響され ない。また， $K_{\mathrm{C}}$ は短絡抵抗が大きく $h$ が大きいと $K_{\mathrm{S}}$ に比 べ小さくなるので無視できる。

〈4·2〉 短絡損失を表す鉄心の等価回路 これらの結 果を近似的に等価回路に示寸と, 眓 6 のようになる。短絡 電流が流れる短絡電気回路は変圧器での 2 次側に対応し, 短絡抵抗は負荷に相当寸ると考える。図中の鉄心部の等価 回路定数は短絡電気回路と鎖交する磁束が流れる磁気回路 (断面積 $w H$, 長さ $\ell$ ) に対応したもので, $L$ はインダクタン ス, $\omega r_{\mathrm{h}}$ と $R_{\mathrm{e}}$ は各々ヒステリシス損 $W_{\mathrm{h}}$, 渦電流損 $W_{\mathrm{e}}$ に 対応した抵抗であり， $R_{\mathrm{e}}$ は，

$$
R_{\mathrm{e}}=N^{2} w H \sigma_{\mathrm{e}} / \ell
$$

である(4)。ここで，Nは鉄心の巻線数である。

等価回路中の $R_{\mathrm{TA}}$ (短絡部抵抗と積層鉄心抵抗の和) は,

$$
\begin{aligned}
R_{\mathrm{TA}} & =N^{2} r_{\mathrm{S}} H+12 N^{2} r_{\mathrm{C}} / H \\
& =R_{\mathrm{e}}\left(1 / K_{\mathrm{S}}+1 / K_{\mathrm{C}}\right) \cdots \cdots
\end{aligned}
$$

であり, 下記の, 精密に短絡損失を算定した值 $R_{\mathrm{T}}$ より小さ く, 最大で約 $11 \%$ 程度 $(h=3.5$ 近傍) 小さいが, 現状の近似 としては十分と考える。

$$
R_{\mathrm{T}}=\frac{N^{2} r_{\mathrm{S}} H}{1-\tanh (h) / h}
$$

この等価回路からも，積層鉄心における短絡損失は無視 できないことが推定できる。

〈4·3〉 モータ形状の影響 モータ(磁極対数 $N_{\mathrm{P}}$, 空 隙部直径 $D$ ) の一体鉄心において, かしめや溶接( 個数 $N_{\mathrm{S}}$ ) の影響を $h$ が大きい場合について検討する。モータ空隙部 の周速と実効磁束密度を $v, B_{\mathrm{e}}$ とし, かしめや溶接が界磁 磁束と鎖交する割合を $q$ とすると, 短絡部は 等価的に磁 束密度 $q B_{\mathrm{e}}$ 中を $v$ で移動することになるので, 短絡部に誘 起起電力 $v q B_{\mathrm{e}} H$ が発生することになり, 短絡抵抗が $r_{\mathrm{s}} H /$ $N_{\mathrm{S}}$ であるので，短絡損失は， 


$$
\begin{array}{r}
W_{\mathrm{S}}=\frac{N_{\mathrm{S}} q^{2} v^{2} B_{\mathrm{e}}{ }^{2} H}{r_{\mathrm{S}}}=q^{2} \frac{N_{\mathrm{S}}}{r_{\mathrm{S}}} \frac{H D^{2}}{4 N_{\mathrm{p}}{ }^{2}} \omega^{2} B_{\mathrm{e}}{ }^{2} \cdots \\
q=1 \text { (歯部), } \leqq 1 \text { (継鉄部) }
\end{array}
$$

となる。いま，鉄心の磁束密度が歯部，継鉄部と共に空隙 磁束密度の $2 \alpha$ 倍で設計するとすれば，スロット幅が歯幅 の $(2 \alpha-1)$ 倍, 鉄心継鉄部幅が $D /\left(4 \alpha N_{\mathrm{P}}\right)$ となるので, 歯部の鉄心体積を考慮した実効継鉄部直径を $\beta D$ とする と，鉄心体積は $\pi \beta D^{2} H /\left(4 \alpha N_{\mathrm{P}}\right)$ となる。従って， $K_{\mathrm{S}}$ は，

$$
K_{\mathrm{S}}=\frac{3 q^{2}}{\pi \alpha \beta} \frac{N_{\mathrm{S}}}{N_{\mathrm{P}}} \frac{\rho_{\mathrm{C}}}{\eta r_{\mathrm{S}} t^{2}}
$$

となる。 $r_{\mathrm{S}}=\rho_{\mathrm{C}} / t^{2}, \quad \eta=1, N_{\mathrm{S}}=3 N_{\mathrm{P}}, \quad \alpha=1, \quad \beta=1$ とす ると $K_{\mathrm{S}}=9 q^{2} / \pi$ となり, 鎖交比率が高くなると, 鉄心素 材鉄損と比較し無視できない大きさとなることが分かる。 かしめや溶接が界磁側の反対の外周側にあれば損失には影 響しなくなる。かしめで， $q=0.1$ であれば短絡損失は素材 渦電流損の数\%で殆ど影響なく無視できる。

〈4·4〉分割鉄心における層間短絡の影響 モータの 電機子巻線の占積率を高くするために，分割鉄心 ${ }^{(5)}$ を用い たモータが使用されている。しかし，モータの鉄心は磁性 部材としての機能以外に，推力の伝達保持の役割も担って いるので，積層鉄心の結束は必須であり，特に，各鉄心セ グメントにおける積層間結束や歯部先端の結束のために, かしめ, 或いは溶接が必要であり, この場合が特に短絡の 影響が大きくなる。そこで，分割鉄心における層間短絡の 影響を検討する。

分割鉄心の層間短絡の例と電気等価回路を図 7 に示す。 図 7 の上図は複数の短絡端が存在する例で，下図は，この 例に対応させた等価回路である。図 7 の B の部分は，短絡 部の誘起起電力に対応する鉄心の等価回路 (図 6 のA) を簡 略化して表示した。同図において， $L_{\mathrm{k}}{ }^{*}$ は図 6 の A に示さ れる $L, \omega r, R$ の並列回路に相当する等価回路の等価イン ダクタンスであり， $R_{\mathrm{S}}\left(=N^{2} r_{\mathrm{S}} H\right)$ はかしめや溶接など (図中 の $\mathrm{a}, \mathrm{b})$ の短絡抵抗， $R_{\mathrm{S} 2}$ は鉄心とケースの接触(図中の $\mathrm{c}$ )で ある。 $R_{\mathrm{CS}}$ は分割鉄心間接触による短絡抵抗であり, 分割 鉄心間の接触抵抗 $\xi_{\mathrm{CS}}$ と接触幅 $w_{\mathrm{CS}}$ として,

$$
R_{\mathrm{CS}}=12 N_{2} \xi_{\mathrm{CS}} w_{\mathrm{CS}} / H
$$

となる。等価回路の $R_{\mathrm{C} 1}, R_{\mathrm{C} 2}, R_{\mathrm{C} 3}$ は短絡電流が鉄心表面 を流れる部分の鉄心抵抗である。

実際には，鉄心セグメントが複数存在するので，同じ回 路が図の $(\alpha),(\beta),(\gamma)$ のように並列に環状に結線した ものになる。これらの複数の回路における誘起起電力の位 相はモー夕磁気回路における電気角に対応させる必要があ り，図 7 では隣接する誘起起電力位相差を $\theta$ とした。

図 7 の各短絡部に誘起される起電力は, 磁束が鎖交する 比率を $q_{\mathrm{k}}$, 各短絡部の電気角を $\theta_{\mathrm{k}}$ とすると,

$$
V_{\mathrm{a}}=j \omega N q_{\mathrm{a}} \Phi \cos \theta_{\mathrm{k}} \quad[\mathrm{k}=\mathrm{a}, \mathrm{b}]
$$

で表せる。図 7 の短絡部 $\mathrm{a} ， \mathrm{~b}$ の電気角が同じであれば，図

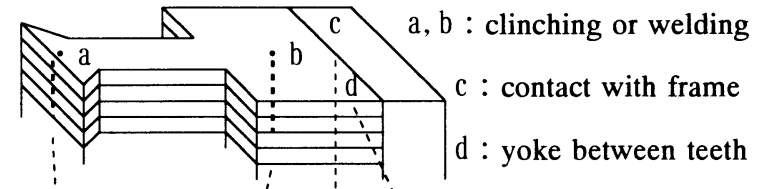

(Śgment core with shqurt circuits)

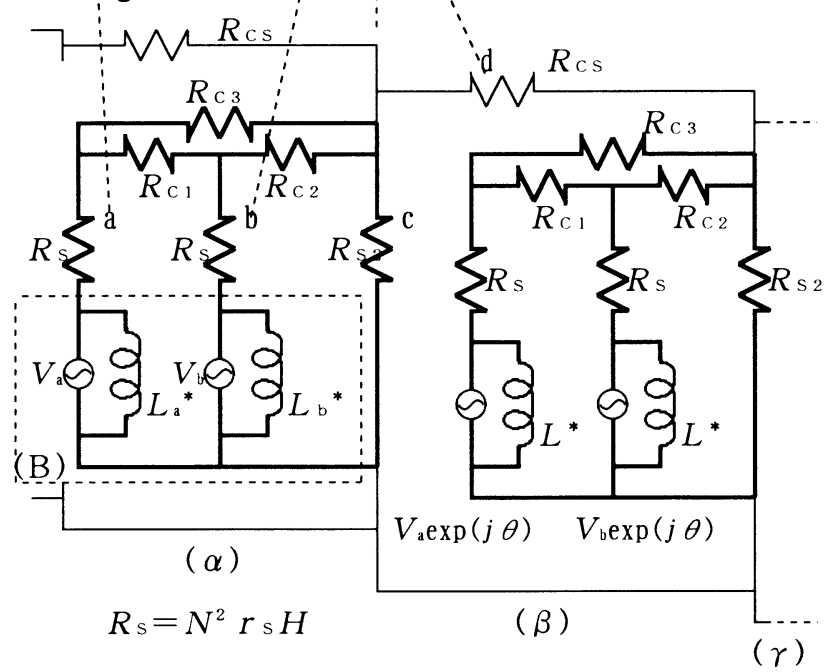

図 7 モータにおける短絡状況の例

Fig. 7. An example of short circuits in a motor core.

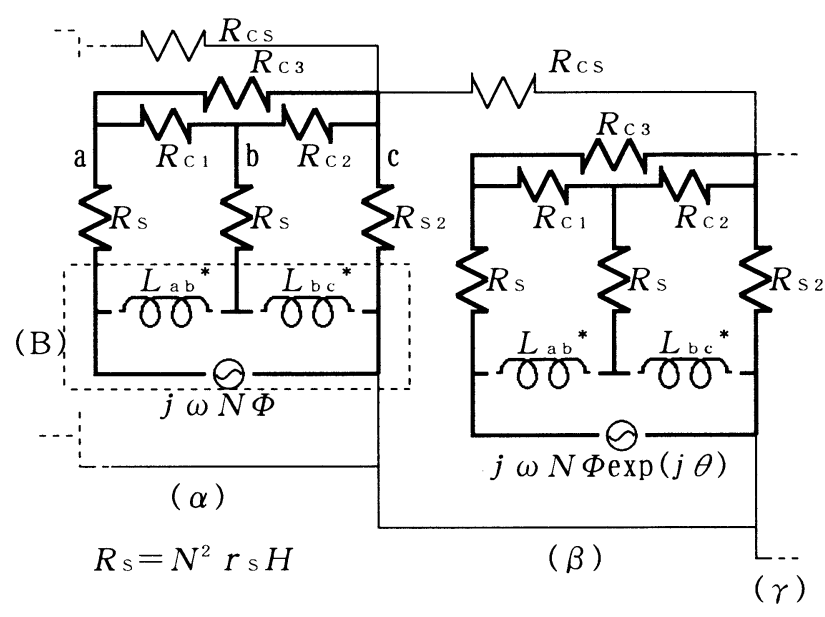

図 8 モータにおける短絡状況の例

Fig. 8. An example of short circuits in a motor core.

8 で表せる。図 8 の (B) で示した部分は図 7 の (B) 部に相当 する。 $L_{\mathrm{ab}}{ }^{*}, L_{\mathrm{bc}}{ }^{*}$ はおのおの短絡部 $\mathrm{ab}, \mathrm{bc}$ の間を通る磁束 に対する等価インダクタンスなどである。この等価回路を 用いると, 短絡電流による反作用の影響もこの等価インダ クタンスなどで予測できる。

分割鉄心間の接触抵抗 $R_{\mathrm{CS}}$ の影響を図 7 , 図 8 の等価回 路で検討してみる。 $R_{\mathrm{CS}}$ が 0 であると, 短絡電流はケース との短絡抵抗 $R_{\mathrm{S} 2}$ を通らず，すべて $R_{\mathrm{CS}}$ を通るので， $R_{\mathrm{S} 2}$ の 影響は無くなる。即ち, $R_{\mathrm{S} 2}=0$ の場合と等価になり, 各短 絡部における短絡損失は(26)式で計算できる。一方， $R_{\mathrm{CS}}$ が 大きくなると $R_{\mathrm{S} 2}$ が影響するようになり，短絡損失は低減 
する。一体鉄心は分割鉄心の $R_{\mathrm{S} 2}=0$ の場合に相当するの で，同じかしめや溶接の数でも分割間の絶縁を行えば分割 鉄心の方が短絡損失は低減できることになる。しかし，実 際には, 分割鉄心は分割数に比例してかしめや溶接が増え るので，短絡損失は増大すると予想される。

モータ性能への層間短絡の影響を検討する場合は，鎖交 磁束に対応する鉄心部の等価回路 ${ }^{(6)}$ に, 図 8 の短絡抵抗や インダクタンス等を組み込めば良い。短絡の影響が大き く, 短絡抵抗が小さくなると, モータ効率だけでなく, 卜 ルクや出力にも影響することも予想される。

$\langle 4 \cdot 5\rangle$ 短絡損失の軽減, 回避方法 以上のように, かしめや溶接, モータケースと積層鋼板との短絡がある と，素材鉄損より大きい短絡損失が生じる可能性がある。

短絡損失を軽減するには短絡抵抗を大きくすれば良く, (14)式より, 鉄心素材の薄手化や高電気抵抗率化を行え ば，短絡損失を低減できる。また，かしめの形状，方法の 最適化による短絡抵抗の増大も重要である。

回避方法としては，かしめや溶接を用いずに積層間結束 を採用寸ることであり, 電気絶縁を考慮したボルト締め, 積層方向の両サイドからの固定や，あるいは，接着被膜電 磁鋼板 ${ }^{(7)}$ などによる積層間接着やモールドを用いると，鉄 心における短絡損失を回避できる。

\section{5. 結論}

本稿では，積層鉄心において，かしめや溶接などで起き る層間短絡について検討した。層間短絡が生じ, 短絡抵抗 が小さくなると，層間短絡電流が流れ損失が増加する。

かしめによる層間短絡抵抗は，鉄心素材の電気抵抗率よ り接触抵抗の影響が大きく, 積層鉄心の板厚の三乗に反比 例する。溶接による層間短絡抵抗は鉄心素材の電気抵抗率 の影響が大きく，板厚の自乗に反比例し，かしめの場合よ り小さくなる。従って, 溶接の場合の短絡損失はかしめの 場合より大きくなる。実際の鉄心における短絡損失は，理 論計算によると，鉄心素材の鉄損より大きくなる場合があ り，特に，分割鉄心ではかしめや溶接の数が多くなるの で，損失が倍増する可能性もある。

このような層間短絡を軽減するには, 鉄心素材の薄手化 や高電気抵抗率化の方法があり, 回避方法としては接着や モールドによる積層間結束の採用が考えられる。

実際の鉄心において，層間短絡による損失の実測は現状 では難しく, 全損失の実測值と解析值の比較による確認し かできない。今後は, シミュレーションによる現象確認を 行うことが重要と考えられる。

最後に，実験などでご協力を頂いた日鉄プラント設計株 新日鐵八幡技術研究所在勤の田中収氏に謝意を表します。

(平成 14 年 9 月 27 日受付, 平成 15 年 2 月 20 日再受付)

\section{文献}

（1）菅原 彰・岩井保夫 - 花井 隆・仲保秀行 - 森永茂樹 - 開道 力： 「高効率モーターの新しい展開」, 総合電気雑誌 OHM, Vol.85, No.4, pp.22-35, オーム社 (1998)

(2) 開道 カ：モータ技術実用ハンドブック, pp.442-447, 日刊工業新 聞社 (2001)

( 3 ) C.Kaido and T.Wakisaka : "Effect of Material Parameters on Iron Losses in Non-oriented Electrical Steel Sheets", T. IEE Japan, Vol.117-A, No.7, pp.685-690 (1997-7) (in Japanese)

開道 力・脇坂岳顕 :「無方向性電磁鋼板の磁気特性に及ぼす素材因 子の影響」, 電学論 A, 117, 7, pp.685-690 (1997-7)

(4) C.kaido : "Equivalent Circuits for Electrical Steel Cores with Distributed Magnetic Properties", J. Magn. Soc. Japan, Vol.19, No.1, pp.39-44 (1995) (in Japanese)

開道 力:「鋼板内磁気特性分布を考慮した電磁鋼板コアの等価回 路」, 日本応用磁気学誌, 19, 1, pp.39-44 (1995)

（5）小形モータの高性能化に関する調査専門委員会 : 電気学会技術報 告, No.744, pp.21-22 (1999)

(6) C.Kaido and T.Wakisaka : "Equivalent Circuits for Motors, Representative of Magnetic Properties", T. IEE Japan, Vol.118-D, No.5, pp.661-666 (1998-5) (in Japanese)

開道 力・脇坂岳顕 : コア素材の磁気特性を考慮したモータ等価回 路の理論検討, 電学論D, 118, 5, pp.661-666 (1998-5)

( 7 ) K.Takeda, R.Ito, C.Kaido, and K.Hirose : "Characteristics of a Heatproof Adhesive Coating of Non-oriented Steel Sheets", 2000 National Convention Record, IEE Japan, Industry Application Society, No.24, pp.207-212 (2000)（in Japanese)

竹田和年 - 伊藤 良・開道 力・広瀬喜久司：「電磁鋼板耐熱型接 着コーティングの特性について」, 平成 12 年電気学会産業応用部門 大会, No.24,pp.207-212 (2000)

開道力 (正員) 1950 年 9 月 7 日生まれ。1975 年 3 月

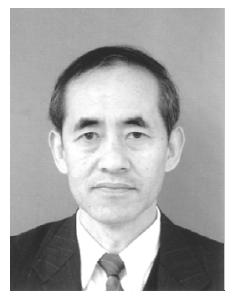
東京工業大学修士課程修了。同年, 新日本製鐵 (株)入社。主として, 電磁鋼板をはじめとする 磁性材料の磁気物性及び磁気応用, 計測などの 研究に従事。現在, 同社 技術開発本部鉄鋼研 究所 鋼材第一研究部 主幹研究員。 工学博士。

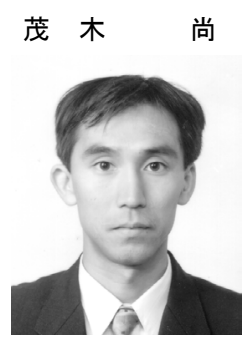

（正員） 1966 年 3 月 6 日生まれ。1990 年 3 月 東北大学博士前期課程修了。同年, 新日本製 鐵 (株) 入社。主として, 電磁鋼板の製造技 術, 磁気物性および磁気応用等の研究に従 事。現在, 同社 技術開発本部 鉄鋼研究所 鋼 材第一研究部主任研究員。工学博士。

半 澤 和 文 (非会員) 1957 年 12 月 4 日生まれ。 1982 年 3 月東北大学理学部化学科卒業。同年新日本製 鐵 (株) 入社。主として, 無方向性電磁鋼板の 製造, 品質管理, 開発に従事。現在, 同社八 幡製鐵所 電磁鋼板工場 電磁鋼板管理グルー プマネジャー。 